\title{
Syrian Refugees' Challenges and Problems of Learning and Teaching English as a Foreign Language (EFL): Jordan as an Example
}

\author{
Heba M. N. Alefesha ${ }^{1}$ \& Dina A.H Al-Jamal ${ }^{2}$ \\ Yarmouk University, Irbid, Jordan
}

\begin{abstract}
This study sought to identify the problems and challenges of teaching EFL to Syrian refugees, and the solutions to the problems. The qualitative research design was employed within a semi-structured interview with ten (10) Syrian refugees, one (1) director of resettlement agency, one (1) EFL manager, and one (1) EFL instructor. The data analysis results showed four (4) important challenges of learning and teaching EFL to Syrian refugees in Jordan. The challenges are social, educational, financial, and institutional. Most of the social challenges were as a result of financial crisis, concerns about immediate family members and other relatives still residing in Syria, childcare, lack of fulfilling basic needs, and mental hazards. Financial challenges came from the inability to afford the regular family expenses, such as food, clothing, and medicine. Educational challenges were mainly as a result of a poor educational background, discomfort with English Language, lack of knowledgeable teachers to deal with the Syrian refugees, and lack of motivation. Budget crisis for meeting the demands of additional learning materials, new class environment, scarcity of teachers and volunteers, and the poor academic background of Syrian refugees are major institutional related challenges. This study recommends that the curriculum of teaching EFL should be designed easily by using less sophisticated and learner-friendly teaching methods. If necessary, EFL teachers should pay extra attention to the teaching of EFL to Syrian refugees. For providing extra effort, the institution should pay extra compensation to motivate teachers.

Keywords: ESL, Syrian refugees, challenges, solution, Jordan.
\end{abstract}

\section{Introduction}

English as a foreign language (EFL) is one of the most popular research issues among researchers and scholars associated with the discipline of English. A large strand of previous studies (Gan, 2013; Kanno \& Varghese, 2010; Lertola \& Mariotti, 2017) is concerned with identifying the challenges and opportunities of EFL in the context of different nations and regions (Sujito, et al. 2019). According to Lertola and Mariotti (2017), EFL stands for those people who have a first language or native language, but want to master English as their foreign language. Similarly, Gan (2013) defines EFL as a discipline, in which learners are educated about English besides their first language. There are numerous benefits of learning English as a foreign language. These include increasing communication skills (Lertola \& Mariotti, 2017), enhancing competency on international language (Gan, 2013), getting employment (Kanno \& Varghese, 2010), increasing workplace efficiency (Nel \& Müller, 2010), increasing social network beyond the nation, and an overall personal and professional benefit. Taking into consideration the importance of EFL, many studies have already been conducted to analyze the pros and cons of EFL in EU, USA, Africa, Asia, and other parts in the World.

If EFL is linked to the Syrian refugee, it becomes an interesting research issue (Karam, Kibler, \& Yoder, 2017). For example, Steele (2017) found that educational, institutional, economic, and social challenges are key obstacles to the learning of EFL by Syrian refugees. Evans and Fitzgerald (2017) conducted a study on Syrian refugees living in the USA and their challenges in learning EFL. They found that most of the Syrian refugees were deprived of their basic needs such as food, shelter, clothing, education, and medicine. This posed challenges to their learning. Also, most of the Syrian refugees faced challenges in getting employment, which caused severe financial crisis. In the face of financial, economic, social, and educational challenges, most of the Syrian refugees could not complete their learning.

Although a large number of studies have been conducted to identify the potential problems and challenges of Syrian refugees in learning EFL (Al Hariri, 2018; Cinkara, 2017; Steele, 2017; Ogilvie \& Fuller, 2016), there is a dearth of research to identify the challenges faced by Syrian refugees, residing in Jordan. Jordan is one of the neighboring countries of Syria. Due to the Syrian crisis, many Syrians came to Jordan to preserve their livelihood. According to Reliefweb (2018), eighty-nine (89) Syrian refugees per one thousand (1000) inhabitants reside in Jordan. In addition, of the Syrian refugees residing in Jordan, eighty percent (80\%) of refugees live below the poverty line, fifty- one (51\%) are children, and four (4\%) are elderly people.

\footnotetext{
${ }^{1}$ Doctor at Faculty of Education, Yarmouk University, Irbid, Jordan. hebbahmansoor@yahoo.com

${ }^{2}$ Associate professor at Faculty of Education, Yarmouk University, Irbid, Jordan Deena.j@yu.edu.jo
} 
Most Syrian refugees live in the refugee camps, where they lead miserable lives. However, many refugee resettlement agencies and Jordanian schools assist in provide learning EFL towards the Syrian refugees so they can get better employment. In the meantime, the Jordanian government has taken initiatives to provide employment to the Syrian people. For getting employment, English learning plays a pivotal role. Although many refugee resettlement agencies and Jordanian camps are contributed to teaching EFL to the Syrian refugees, most of them do not complete their learning (Reliefweb, 2018). The drop rate is increasing gradually. This raises concern among the resettlement agencies and associated parties in terms of the continual increase in the drop rate. It opens up a question, "what are the core problems and challenges of Syrian refugees in Jordan in terms of teaching EFL?" This study helps to resolve this question.

\section{Statement of the Problem}

This study is centralized on the problems faced by the Syrian refugees in Jordan, in terms of learning EFL. Conversely, it focuses on identifying the challenges and problems of teaching EFL to these refugees. Previous studies (Alcantud Diaz, 2016; Cinkara, 2017; Miles \& Bailey-McKenna, 2016; Tarman \& Gürel, 2017) have identified several problems faced by Syrian refugees in terms of learning EFL. Alcantud Diaz (2016) reveals that most Syrian refugees are mainly concerned with fulfilling their needs such as, food, shelter, and clothing. Thus, education is less important for them. Conversely, Clark (2017) shows that poor education among Syrian refugees is a major obstacle of getting employment.

Similarly, Li, Doyle, Lymburner, and Ghadi (2016) shows that most of the EFL teaching is provided in the refugee camp and nearby areas, where learning environment is very poor due to noise, and the haphazard situation. The women are busy at childcare, whereas the men are concerned about getting employment. Thus, they cannot give full attention. As suggested by Karam et al., (2017), skill gap of teachers often impose challenges to teach EFL towards the Syrian refugees. In addition, they claim that most of the Syrian people are mentally upset and unfit. Teachers, therefore, should pay extra attention to teach them EFL. Although previous studies have identified several challenges of teaching EFL to Syrian refugees, most of them are beyond the Jordan. To the best of knowledge, there is a dearth of literature in identifying the challenges and problems of teaching EFL to Syrian refugees in the Middle East.

According to Steele (2017), educational, institutional, economic, and financial factors, make four (4) important challenges, faced by Syrian refugees in terms of learning EFL. This study is limited to the US. Thus, it is not worthy to generalize the problems and challenges of teaching EFL towards the Syrian refugee based on this study. Therefore, it has become a burning issue to conduct a study in terms of identifying and interpreting the challenges and problems of teaching EFL to the Syrian refugees.

\section{Significance of the Study}

The study strives to explore the problems and challenges of teaching EFL to Syrian refugees in Jordan. The study has several theoretical and practical contributions. Theoretically, the study will initially go through the extant literature on the problems and challenges of teaching EFL to Syrian refugees. The literature survey adds value by identifying the core challenges and problems of Syrian refugees in terms of EFL. This helps to draw the initial theoretical framework.

Besides, it contributes to identifying the constraints and limitation of the academic literature. If the literature is inadequate in resolving the research problem, it attempts to enrich the theory by conducting an investigation on the problems and challenges of Syrian refugees in terms of EFL. The investigation plays a crucial role in understanding and better explaining the problems and challenges of teaching EFL to Syrian refugees.

The qualitative interview helps in direct communications and conversations between the EFL teachers and the Syrian refugees. After understanding the views, opinions, and experiences of the participants, the study creates a pattern and theme that helps furnish the present theory and literature.

Practically, the study has several benefits. First, it contributes to providing realistic and up-to-date information about the problems and challenges of teaching EFL to Syrian refugees. Based on the information, the policy makers and concerned parties can make suitable decisions on improving the methods and approaches in teaching EFL to the Syrian refugees. The results of the study provide an in-depth understanding about the challenges and problems of teaching EFL. This educates the learners and helps them understand the problems and challenges of EFL faced by refugees such as the Syrian refugees in Jordan. Moreover, the results of the study are validated by academic experts. Thus, the study contributes to the enrichment of both practical and academic fields. 


\section{Literature Review}

Problems facing Refugees in learning a Foreign Language

Foreign language refers to a language which is not native to the speaker, and is not widely used by the individuals of a society, community or country (Burgoyne \& Hull, 2007; Hulistijn, 2011; Gizatullina, Sibgatullina, 2018). People, especially refugees, face a lot of problems in terms of learning a foreign language. For example, refugees who are attending EFL classes do not understand the pronunciations of the native English speaker (Al Hariri, 2018). The fact is they do not see the value of the EFL classes in assisting their understanding of the target language.

The extent literature Riggs et al., (2012) depicts that learning of foreign languages by the refugees come in two-folds. First, they learn foreign language in terms of surviving in the target country. Second, they simply want to get a job. Further research by Al Hariri (2018) found that the majority of the women's refugees do not attend classes due to the lack of childcare centers.

Similarly, Popov and Erik (2015) showed that lack of childcare center in the learning organization may hinder refugee women from attending classes, as their children cannot join them or be with other children for cultural reasons. In addition, Baynham (2006) found that refugee students cannot be full time students, because they work to earn money or are looking for jobs by day. They join the classes only at night. The extensive literature, claimed that the students who are refugees require more time to learn foreign language due to several reasons which include; unfamiliarity of the language (Aydin \& Kaya, 2017, 2019; Riggs et al., 2012), new teachers and classmates (Al Hariri, 2018), new organization (Popov \& Erik, 2015), new society (Burgoyne \& Hull, 2007) and so on.

Further research by Baynham (2006), found that cultural and religious heterogeneity is the main reason for refugee women not attending classes with males present. Besides, Watkins, Razee, and Richters (2012) showed that many refugees are facing problems in classes, especially those who did not have a formal education. By supporting this statement, Casimiro, Hancock, and Northcote (2007) claimed that refugees who did not have any previous formal education, needed more time and hours to capture or cope with the new environment, new people and society as well as the new language. In this regard, Riggs et al., (2012) suggested that the refugee students consider investing more time to learn the foreign language and practice more and more and use the language in their daily communication.

Perry (2013) argues that refugees face big challenges as regards economic support, therefore they do not attend language classes. The fact is that refugees want to earn money to support their family and they assume that the time invested in language class, is less important than time they spend in earning money. Further study by Riggs et al., (2012) identifies that refugees are faced with institutional problems, because they cannot adjust with the new environment, teachers and instructors. In his study Lee (2016), showed that refugee students face social problems, because they come from a different background that restricts them from associating with people from other backgrounds. Therefore, they cannot openly and confidently interact with their classmates. The author also claimed that refugee students are facing problems in language class due to their age variation. The fact is that in a language class, the refugee students hold different age profiles that make it difficult to freely interact with each other.

On the other hand, they face problem to attend mixed gender class. In their study, Popov and Erik (2015) found that the majority of the women refugees feel shy to attend mixed gender language classes. This unwillingness to attend the language class imposes a great barrier to them as to learning their target language. In addition, Riggs et al., (2012) claimed that cultural and religious factors impose challenges on refugees as to learning English and other target languages. The authors also explained that refugees especially women do not attend language classes due to their cultural and religious barriers.

In his study, Frimberger (2016) illustrated that the level of education obtained by the refugee students in their own language or home country, plays a crucial role in learning the target language or foreign language. Similarly, Olliff and Couch (2005) found that refugees, who did not have any formal learning in their own language or home country, face more challenges than who had formal learning in their own language in terms of learning foreign language. Many scholars (Arslan \& Tanıs, 2018; Carr \& Inctas, 2018; Casimiro et al., 2007; Kagema, 2018; Riggs et al., 2012; Watkins et al., 2012) believe that new classrooms, new teachers, new classmates and overall new organizational environment, create numerous challenges for the new students especially those learning a second or foreign language. Besides, Stevenson and Willott (2007) claimed that the family, country and cultural background of refugees may serve as hindrance in the way of learning the foreign language by the refugees.

In contrast, sometimes, teachers are considered or treated as refugees while teaching in the classroom and that poses as a challenge to the refugee students (Baynham, 2006; James, 2018; Yigit, 2018). Further study by Bond et al., (2007), depicts women refugees as facing more problems than their male counterparts because 
they are responsible for childcare as well as caring for their family members. In addition, Popov and Erik (2015) argue that women are shyer than men when it comes to interacting with their classmates and teachers in the classroom or other formal setting of learning such as seminars on learning foreign languages. However, scholars, researchers, and academicians (Al Hariri, 2018; Bond et al., 2007; Riggs et al., 2012; Watkins et al., 2012) suggest that organizations should arrange classes by using interesting approaches, and visual methods so that refugee students can learn their target language in an interesting and convenient learning environment.

As earlier mentioned, refugees are facing a lot of problems in terms of learning a foreign language. Similarly, refugees are facing numerous challenges in order to learn English as a foreign language or enroll in EFL programs. Bond et al., (2007), claimed that teachers and other academic members of EFL programs who address the refugees, should be evaluated, taught, and assessed very carefully so that they can learn and improve their foreign language knowledge and skills. By supporting this argument, Riggs et al., (2012) illustrated that teachers are required to give attention to those students who come from different educational backgrounds as well as different cultural, religious and ethnic backgrounds.

In their research Popov and Erik (2015) found that a majority of the refugees are engaged in EFL programs and other foreign language classes in order to get financial and other supports that are provided by the governments. That's why their attention is not fully focused on learning. Rather, they focused on other benefits of the EFL programs; therefore, they do not gain sufficient knowledge in any particular language. Burgoyne and Hull (2007) found that in spite of having attending a foreign learning language program twice, most of the refugees did not speak well in English. When asked why, they claimed that they could not understand what the teacher and instructors taught them. In this situation, scholars (Bond et al., 2017; Stevenson \& Willott, 2007; Watkins et al., 2012) argue that teachers and mentors of EFL and other foreign learning programs required to identify the actual reason of problems that faced by the refugee students in terms of learning targets foreign language.

However, there are several problems that are faced by the refugees' adult, women, and children, when they attend a language class. These include difficulty adjusting to unfamiliar faces in the class (Watkins et al., 2012), religious and cultural barriers (Riggs et al., 2012), gender issues (Popov \& Erik, 2015), language problem (Bond et al., 2007), age related problem (Casimiro et al., 2007), social problem (Lee, 2016), economic problem (Perry, 2013), institutional problem (Riggs et al., 2012) and so on. Scholars argue that until these problems are resolved, refugees do not achieve actual learning from the language classes.

\section{Qualification of EFL Teachers}

Teachers have a significant role to teach the refugee students because it is a critical task to teach the people who came from the different family, cultural, educational and country backgrounds. However, teachers in EFL programs are faced with numerous challenges to conduct the classes, because the refugee students do not adjust with the new environment, new organization and teachers, as well as the unfamiliar faces (Cinkara, 2017). Therefore, teachers face several challenges to involve them in a formal educational setting.

Van Rensburg and Son (2010) depict that teachers need to invest more time and effort in terms of identifying the right methods and materials that make easy the learning process to the people who want to learn the target language. In spite of having experience of some teachers, the majority of the teachers or volunteers who have engaged to teach the refugee students, do not have any qualification certificate (Lee, 2016). Al Hariri (2018) claimed that most of the teachers or volunteers face challenges during teaching the refugee students, due to the lack of their experiences. This argument is supported by Gan (2013) who depict that many instructors who engaged in teaching adult refugees had not any professional certificate to lead the adult literacy classes. Similarly, Karam et al., (2017) found that many of the teachers were not well trained and lacked the knowledge and experiences to teach the refugee students in a formal class.

In their study, Riggs et al., (2012) illustrated that certificate or professional qualification is important for a teacher or instructor who teaches the refugees, because it helps the teachers to conduct the classes in an effective and interesting way. Stevenson and Willott (2007) claimed that the refugee students are more likely to attend those classes which are conducted by well trained and experienced teachers. Similarly, Watkins et al., (2012) found that the teachers who have got training or other qualification certificate, they can conduct the class with the help of different methods and approach. Therefore, students are more likely to attend their classes attentively. Furthermore, Lee (2016) identified that the teachers who have certificate can manage materials and other accessories from the refugee resettlement agencies and government. Van Rensburg and Son (2010) specified that many of the teachers and instructors are voluntarily involved in teaching of refugees, and therefore, they do not receive any kind of professional training and certificate from any government permitted organizations or institutions. 
Scholars suggest that teachers; who teach the refugees, require appropriate training and other professional support to enable effective course delivery for the benefit of the two parties (teacher and students). Besides, Lee (2016) noted that knowing the underlying causes of problems faced by individual refugees will help provide effective solutions.

Methodologies used to teach Refugees a Foreign Language

As mentioned earlier, conducting a class in order to teach the refugees is a crucial task and needs professional training and experiences. The fact is, refugees come from different educational, cultural, religious, and society background, that's why it is not an easy task to teach them in a formal classroom. In mainstream literature, scholars, researchers, and practitioners develop different methods and approaches to teach English and other target languages to refugees. Perry (2013) depicts that teachers are required to follow acceptable and scientific method in terms of conducting classes to teach refugees. The fact is that applying proven methods of tutoring makes learning easy for refugee students and encourages them to attend classes (Miller, 2009).

A research conducted by Lee (2016) developed a method to teach English language and computer literacy to the refugee students. He assumed that it is easy to teach English language and computer skill to refugees through computer playing games, including crossword puzzle, food games, critical reasoning, vocabulary cross-matching, and so on. It assisted them in learning English language and computer skill in their subconscious mind. In supporting this argument, Alcantud Diaz (2016) illustrates that teaching English and computer literacy through playing games is a very fruitful way to teach the people whose native language is not English. Since people are more likely to work or play on computer, they learn words, vocabularies and computer skills in the process aiding literacy.

Werge-Olsen and Vik (2012) argue that classes are required to maintain high flexibility to prevent boredom. The authors depict that teachers involved in EFL classroom training need to ensure easy learning. The authors also found that some students could feel bored due to their age, gender, ethnicity, and culture and therefore teaching should be tailored to such individuals.

Steele (2017) developed a method to teach the refugees namely "let them take control of their own education". This means that they are taught in a way that is associated with their own language. The authors believe that learning is easier for the refugees when it matches their own education. He suggests encouraging them to work in groups, teams and sub-teams and learn with each other. On the other hand, Perry (2013) critics that it is difficult to apply "let them take control of their own education" method, because many of the refugees were not educated in their language and hence, struggle with understanding the classes. The authors also claimed that this method is easier only for students educated in their own languages.

Baynham (2006) proposed a method to teach refugees that allows them to learn interestingly. In this method, at first teachers guide students on how to read and write, and later divide the students into several subgroups, and assigned task that would be solved by the group members. The authors also claimed that after solving a task, the group members are inter-changed with other groups to assign new task. He believes that this way allows them to introduce each other and form solid relationship amongst themselves. The authors found that this approach increased the reading skills and problem solving skills. It also encourages them to practice at home and motivates to improve their language skills.

However, Lee (2016) found that the vocational approach which enables the refugees to learn language skill and job skill at the same time is the best method to teach them. The fact remains that refugees are more likely to attend those language classes that allow them to learn both language skills and job skills. This statement is supported by Riggs et al., (2012), who claimed that women refugees are more involved in vocational classes, because they want to learn language and job skills that will enable them to get a job and earn money for the family. For example; women refugees are more likely to be involved in those classes where basic skill such as cooking, and sewing class are taught to aid job security in the future.

So, this study assumes that the best way to teach adult refugees is to arrange vocational classes, where they learn both language skill and professional skill by which they can get a job after finishing their education. On the other hand, it reviews that the two interacting class is the best approach to teach the refugee children as it allows them to gain language skills, communication skills, problem solving skills and in the development of good interpersonal relationships (MacNevin, 2012). In addition, from the literature survey, the study also found that teaching refugees through computer playing games is an effective way to teach refugees students which help them gain knowledge in both English language skill and basic computer skills aiding job security in the future. 


\section{Aims and Objectives}

The aim of this study is to investigate the problems and challenges of teaching EFL to Syrian refugees, and to develop strategic roadmap in terms of overcoming problems and challenges of learning and teaching EFL. The objectives are structured as follows.

- To carry out a literature survey to understand what previous studies reveal about the challenges and problems of teaching EFL to Syrian refugees, residing in different parts of the world.

- To identify and better interpret the challenges and problems of learning and teaching EFL to Syrian refugees by conducting in-depth semi-structured interview with Syrian refugees.

- To develop a strategic roadmap for overcoming the challenges and problems of learning and teaching EFL to Syrian refugees

\section{Research Questions}

- What are the challenges and problems of learning and teaching EFL to Syrian refugees by conducting in-depth semi-structured interview with Syrian refugees?

- What are the ways of overcoming the challenges and problems of learning and teaching EFL to Syrian Refugees?

\section{Methods and design of the study}

The study aims to identify the problems and challenges of teaching EFL to Syrian refugees in Irbid, Jordan. Besides, the study attempts to identify solutions for overcoming the challenges and problems of teaching EFL. The study is exploratory by the nature (Bryman \& Bell, 2015). The reason is that the problem of the study is not fully understood and the exploratory study attempts to find out the problems and to devise solutions for overcoming problem (Saunders, Lewis, \& Thornhill, 2009). The key motivation of the study is to identify and resolve problems of teaching EFL to Syrian refugees. The study adopts qualitative method to explore the problems of teaching EFL. There are several justifications of using qualitative method in the study. First, the extant literature is not enough to identify the actual problems of teaching EFL to Syrian refugees in Irbid, Jordan. Thus, it is crucial to explore the problems by obtaining in-depth information about what is happening in terms of teaching EFL to Syrian refugees. Second, an in-depth semi-structured interview helps collect in-depth information from the Syria refugees about their knowledge, ideas, and experiences about EFL learning. Semistructured interview with resettlement agency and EFL instructors, further aids better interpretation of problems and generation of patterns or themes that would assist to enrich extant literature (Bryman \& Bell, 2015). Third, the qualitative method helps to collect and better interpret the human views, opinions, and knowledge by conducting interviews (Saunders et al., 2009).

According to Gupta (2011), the qualitative method assists collection of subjective data and interpretation of the data in order to demonstrate the actual problem and scenario. The qualitative method helps to understand the actual problems and challenges of teaching EFL to Syrian refugees. Thus, the qualitative method is a suitable method for the current study.

\section{Population and Sampling}

The target population of the study is the Syrian refugees in Irbid, Jordan. According to Zikmund, Babin, Carr, and Griffin, (2013), at present nighty-eight (98) out of one thousand (1000) inhabitants live in Jordan. Apart from the Syrian refugees, the study considered the resettlement agency and EFL instructors or teachers as the target population of the study. As it is difficult for the study to collect data from all population, the study adopted purposive sampling technique to determine the sample size. According to Bryman and Bel (2015), purposive sampling is fit for the qualitative research, which aims to understand complex problems, rather than maximizing the response rate. The study underpinned purposive sampling method in order to reach the target audience easily. The application of purposive sampling method enabled the determining of ten (10) Syrian refugees, one (1) director of resettlement agency, one (1) EFL manager, and one (1) EFL teacher. The study initially communicated with the directors, EFL manager, and EFL teacher to collect data. Then, it asked ten (10) Syrian refugees to attend EFL class to educate them about the purpose and objectives of the study. 
Table 1.

Demographic characteristics of the Participants

\begin{tabular}{llcc}
\hline Participants & Age & Marital Status & Gender \\
\hline Participant A & 30 & Married & Female \\
Participant B & 32 & Married & Male \\
Participant C & 34 & Married & Male \\
Participant D & 28 & Married & Male \\
Participant E & 22 & Married & Male \\
Participant F & 26 & Married & Male \\
Participant G & 33 & Married & Male \\
Participant H & 39 & Married & Female \\
Participant I & 42 & Married & Male \\
Participant J & 45 & Married & Male \\
Participant K (EFL Manager) & 49 & Married & Male \\
Participant L (Office director) & 52 & Married & Male \\
Participant M (EFL teacher or instructor) & 48 & Married &
\end{tabular}

The study conducted semi-structured interviews with ten (10) Syrian refugees. All were married. The age range of the participants were between twenty-two (22) and forty-five (45) years. In terms of gender, two were female, and the rest were male. Apart from the ten (10) Syrian refugees, the study conducted semistructured interview with one (1) EFL manager, forty-nine (49) of age, one (1) office director, fifty-two years (52) of age, and one (1) EFL teacher, four-eight (48) years of age. All three were married females.

\section{Data Collection Instruments}

The study used semi-structured interview questionnaire to collect data from the respondents. Prior to finalizing the semi-structured interview questionnaire, a pilot test was conducted on one participant. The key purpose of conducting the pilot test was to identify any problems or errors, check out the layout, formatting, grammar, and sentence structure of the questionnaire. After obtaining feedback, it was finalized. The semistructured interview questions are inserted at the appendix I.

\section{Data Collection Administration}

The units of analysis of the study were the Syrian refugees, a director of resettlement agency, an EFL manager, and an EFL teacher. Prior to collecting data from the participants, it was initially shown to the director of resettlement agency associated with teaching EFL. After obtaining the permission of the director, the researchers visited his office and conducted a semi-structured interview. With the assistance of the director, the researchers communicated with the Syrian refugees, one EFL teacher and one manager. Then the researchers conducted the semi-structured interview with the EFL manager and teacher in their office. In order to collect data from the Syrian refugee, the researchers called for some of them attending an EFL class, where they were informed about the nature and purpose of the study. Then, the researchers distributed a consent form to each participant. After obtaining participant's consent form, the interview was conducted with every single participant. The interview time period was four (4) days. The duration of each interview was thirty to forty (3040) minutes approximately.

\section{Data analysis}

The study collected data from participants by conducting semi-structured interview. In order to analyze the qualitative data, it had to underpin the thematic analysis. In order to apply thematic approach of data analysis, the collected data was initially read out to get the meaning. Then the information was coded to identify suitable themes. The study identified four important themes to analyze the data, including social, financial, educational, and institutional challenges. Then the results were interpreted as per the identified themes. Moreover, the study obtained information about the solutions to overcome the problems and challenges of teaching EFL to Syrian refugees.

\section{Ethical considerations}

The study complied with ethical considerations. For the collection of data, it was stated on each participant's information sheet, the purpose and objectives of the study. Further, the study distributed a consent form to all participants. The study informed participants that they could withdraw from the study at any time without stating any reason. The study further complied with the principle of anonymity, and confidentiality. The 
study did not use the name of participants in order to comply with the principle of anonymity. Furthermore, the study stored data with on a laptop, using strong a password, making the data inaccessible. After addressing the purpose of the study, the data will be destroyed permanently.

\section{Limitation of the study}

The study has several limitations. Firstly, the study is limited to Syrian refugees in Jordan who learn EFL. Thus it is not possible to generalize the study with other people who learn EFL but reside in Jordan and different parts in the world. Secondly, the study is limited to a small sample size, because the study aims to understand the problems and challenges of teaching EFL to Syrian refugees, rather than maximizing the response rate.

\section{Analysis and Results}

The study initially examined the obtained information closely. A thematic approach was able to categorize the information into four important themes including social, financial, educational, and institutional challenges. The study further categorized the solution of resolving challenges based on these four selected categories.

\section{Theme One: Social related challenges}

In the interview, all participants agreed that they suffered from numerous social challenges ranging from immediate family support to addressing the basic needs of their family. Interviewees pointed out that they always feel distressed because they were not capable of addressing the basic demands of their family, such as food, shelter, clothing, and medicine. Also, they were tensed about their relatives who were still residing in Syria. Coming from Syria, most of the refugees suffered from mental crisis so they needed to regularly visit the doctor. Also, they were often required to go the government offices for submitting documents in terms of immigration. This often served as obstacles to their learning EFL. One of the participants, a female, aged thirtytwo (32) said;

"Amidst facing challenges to satisfy our needs of food, accommodation, clothing, medication, and safety, it is difficult for us to successfully complete the EFL learning..."

All of the participants agreed that most of Syrian refugees in Jordan needed to regularly check up their health conditions, because they were suffering from severe physical and mental challenges. A male participant aged thirty-four (34) stated;

"We are required to regularly visit the doctor to treat our children, who are still suffering from the trauma of the Syrian crisis. Even, they are required to provide vaccination and other medical treatment to prevent diseases..."

Of all participants, three interviewees claimed that anxiety, depression, and frustration are common issues they deal with because of the severe financial crisis. Thus, domestic violence, malnutrition, abuse, and crime are common among Syrian refugees. With a lot of problems, it is really hard to continue the learning of EFL. One of the participants who was an EFL teacher claimed that the social challenges of the Syrian refugees are apparent in their face and body condition. One of the participants who was a married female said;

"We have to spend most of our time in childcare and family support. So, it is tough for us to give extra effort to learn EFL..."

Drawing on the analysis of the social problems and challenges of teaching EFL, it is clear to say that most of these social challenges are derived from the financial crisis, concerns about immediate family members and other relatives still residing in Syria, childcare, lack of fulfilling basic needs, and mental hazards.

\section{Theme Two: Financial challenges}

All interviewees emphasized on their financial challenges or monetary concerns. They agreed that they prioritized fulfilling the basic needs of their family. Thus, they had to search employment. However, the earning opportunity for them is very low because they are not citizens of Jordan. Although the Jordanian government provides financial support to the Syrian refugees, they are still inadequate. Many resettlement agencies outside the government also provide financial support to them. This support is still not still adequate in fulfilling their basic needs. One of the participants aged twenty-eight (28) stated;

"I have often faced tremendous financial challenges when trying to afford basic consumer goods, such as food, and clothing. Thus, I can't feed regular meals to my children. In the meantime, I have to search for employment and go outside the refugee camps. When I earn some money, I send it to my family, who are residing in refugee camps..." 
Lack of monetary support is a big economic challenge for the Syrian refugees and hinders them from learning EFL. This was echoed by all of the interviewees during the interviews. Four (4) participants said that to learn EFL they must spend some money for educational purposes, although the institution provides some compulsory books and learning materials to them. As their mind is always stuck on financial problems, it is impossible for them to give full attention on learning EFL. On the other hand, one participant who was an EFL teacher claimed that most of the EFL learners do not feel comfortable with EFL, as their native language is Arabic. Thus, it is challenging for them to complete the EFL learning. Economic challenges are major obstacles to teach and learn EFL as the refugees cannot get proper employment opportunities for a better livelihood. Thus they called for an increase in government assistance and support from the resettlement agency.

\section{Theme Three: Educational challenges}

During the interviews the study found that the educational qualifications of the participants were between elementary school and high-school. Thus, they were not advanced academically. Even, all of the participants claimed that they intended to give full attention on class, but they couldn't due to their economic and social challenges. One of the participants aged thirty (30), depicted that:

"Although the EFL teachers made high effort to teach them EFL, they often couldn't understand what the teachers wanted to say. However, since the EFL teachers in Jordan know both Arabic and English, it supports them..."

Although all participants claimed that the EFL teachers made their best efforts to teach them EFL, their poor academic education is a major challenge of learning EFL. Three of the participants claimed that their class environment was not very comfortable for them, due to the crowds and noise. Four of the participants agreed that the EFL teachers were often more likely to follow academic language, especially book language to teach EFL. Since the participants are not familiar with the book language, it is very difficult for them to teach EFL. Furthermore, the Syrian refugees are not comfortable with speaking, writing, and reading English, as their native language is Arabic. For most cases, the learners lacked motivation, because they did not know the benefits of learning EFL.

However, all of the participants claimed that most of the challenges of learning EFL in terms of education include poor educational background, discomfort with English, lack of knowledge of teachers to deal with Syrian refugees and lack of motivation.

\section{Theme Four: Institutional related challenges}

During the interviews, all of the participants claimed that they were unfamiliar with the new environment and class atmosphere. Thus, it was challenging for them to cope with the new environment. Three of the participants noticed that they often faced budget crisis to afford their learning materials. On the other hand, it is quite complex for the institution to afford the funding for additional materials. Most of the institutions are headed by the resettlement agency that collect fund via donation. As this institution is not for profit organization, they can't address the budget crisis. It often hinders the proper teaching of EFL. One of the participants who was the EFL teacher agreed that budget crisis for meeting additional requirements is one of the most vulnerable challenges to teach EFL. According to one of the participants,

"Generally, the lack of available volunteers and teachers cause problem to learn EFL. In some cases, we returned back to our refugee camp from the class without the appearance of a teacher..."

However, the study found that budget crisis for addressing the demand of additional learning materials, new class environment, scarcity of teachers and volunteers, and poor academic background of Syrian refugees are major challenges under the institutional related challenges.

\section{Suggested Solutions against Challenges \\ Solution to Social Challenges}

During the interviews, participants were asked to share their knowledge about the way of resolving social challenges. All of the participants claimed that the Jordanian government should be more cooperative in making life in Jordan more comfortable. The resettlement agency should pay close attention to monitor the ongoing problems and challenges of Syrian refugee. All participants believe that medical support, accommodation support, and financial support would help them resolve their ongoing social challenges. This would enable them to increase their efforts in learning EFL. The help of third party agencies and other NGOs were sought to work accordingly with resettlement agency in terms of teaching EFL. 


\section{Solution to Economic Challenges}

All Syrian refugees during the interviews agreed that the Jordanian government should increase budget needed to support the refugees. This will contribute to the learning of EFL. Three of the participants called for visit of the country leaders, civil society members, and good citizens to help refugees maximize their effort to learn EFL. All participants agreed that government support, coupled with the assistance of civil society will enable them to learn EFL smoothly.

\section{Solution to Educational Challenges}

Highlighting the educational challenges, all of the participants suggested that the government should support the EFL teaching institution so that they can help refugees to overcome educational barriers. All participants proposed recruiting of more volunteers and teachers so that they can teach EFL by using the convenience methods and techniques. All participants also suggested that the curriculum of teaching EFL should be more flexible and learner friendly so that they could learn quickly. Even, the use of technology in the classroom will increase the interest of participants to learn EFL easily and quickly. For example, watching videos, playing computer games and software for grammar learning and sentence making will increase the interest of the participants to learn EFL.

\section{Solution to Institutional Challenges}

All participants believed that the Jordanian people should support the EFL teaching institution so that they can provide essential learning materials to the EFL learners. Furthermore, they requested for the hiring of talented, skilled and competent teachers, who can teach EFL effectively and appropriately. Moreover, they pleaded for government assistance to resolve the institutional challenges.

\section{Findings and Discussions}

The study has found that social, educational, financial, and institutional are four important challenges of learning and teaching EFL to Syrian refugees in Jordan. According to the results of the study, most of the social challenges are derived from the financial crisis, concerns about immediate family and relatives who are still residing in Syrian, childcare, lack of fulfilling basic needs, and mental hazard are severe social challenges for the Syrian refugees in terms of teaching EFL. This finding is supported by Al-Hariri (2018), who found that the Syrian refugees suffered from extreme financial challenges that impose barrier on learning EFL. Besides, the study revealed that most of financial challenges are centralized to afford the regular family expenses, such as food, clothes, and medicine. Even, they can't get proper employment opportunity to live their livelihood.

The result is consistent with the study by Popov and Erik (2015), who showed that financial crisis, increased the drop rate of learners. Further, the study found that most of the challenges of learning EFL in terms of education include poor educational background, discomfort with English, lack of knowledge of teachers to deal with Syrian refugees, and lack of motivation. The result is consistent with the previous studies (Riggs et al., 2012). Moreover, the study found that budget crisis for addressing the demand of additional learning materials, new class environment, scarcity of teachers and volunteers, and poor academic background of Syrian refugees are major challenges under the institutional related challenges.

According to the results of the study, the Jordanian government should be more cooperative to live in Jordan comfortably. The resettlement agency should pay close attention to monitor the ongoing problems and challenges of Syrian refugee. This is complied with Lee (2016). All participants agreed that government support, coupled with the assistance of civil society, and country leaders will enable them to learn EFL smoothly. The curriculum of teaching EFL should be more flexible and learner friendly so that they can learn quickly. Even, the use of technology in the classroom will increase the interest of participants to learn EFL easily and quickly. Moreover, the institution should hire talented, skilled and competent teachers, who can teach EFL effectively and appropriately.

\section{Conclusion}

The key purpose of this study was to identify the problems and challenges of teaching EFL to Syrian refugees and to identify the solutions to the problems. The study has successfully met the purpose by conducting semi-structured interview with ten (10) Syrian refugees, one director of resettlement agency, one EFL manager, and one EFL instructors. The thematic analysis results show that poor social status, limited education, limited finance, and poor institutions are four important challenges of learning and teaching EFL to Syrian refugees in Jordan. Most of the social challenges are derived from the financial crisis, concerns about immediate family and relatives who are still residing in Syrian, childcare, lack of fulfilling basic needs, and mental hazards. Most of 
financial challenges are centralized to affording the regular family expenses, such as food, clothes, and medicine. Most of the challenges of learning EFL in terms of education include poor educational background, discomfort with English, lack of knowledge of teachers to deal with Syrian refugees, and lack of motivation. Budget crisis for addressing the demand of additional learning materials, new class environment, scarcity of teachers and volunteers, and poor academic background of Syrian refugees are major challenges under the institutional related challenges.

\section{Pedagogical Implications and Recommendations}

Based on the results and findings of the study, the researcher provides the following suggestions for the resettlement agency, EFL manager, EFL instructors, and associated parties.

- The curriculum of teaching EFL should be designed easily by using sophisticated and learner-friendly teaching methods. If necessary, EFL teachers should pay extra attention when teaching EFL to Syrian refugees. For providing extra effort, the institution should pay extra compensation to motivate the teacher.

- The use of technology in the classroom will increase the interest of participants to learn EFL easily and quickly. For example, watching videos, playing computer games, and software for grammar learning and sentence making will increase the interest of the participants in learning EFL.

- Jordanian people should support the EFL teaching institution so that they can provide essential learning materials to the EFL learners.

- The Jordanian government should be more cooperative in making Jordan more comfortable to live in. The resettlement agency should closely monitor the ongoing problems and challenges of Syrian refugees.

- Further research ground. The study is limited to qualitative research within a poor sample size. It does not fully present the problems and challenges of teaching EFL to the Syrian refugees. Thus, a quantitative research is necessary to overcome this limitation and validate the results of the above study.

\section{References}

Al Hariri, B. (2018). Teaching ESL to Syrian refugees: Problems and challenges (Doctoral dissertation) University of Toledo.

Alcantud Diaz, M. (2016). Digital storytelling with pre-service teachers. Raising awareness for refugees through ICTS in ESL primary classes. Digital Education Review, 30, 1-16.

Arslan, C., \& Tanis, B. M. (2018). Building English Vocabulary Schema Retention Using Review Value Calculation for ESL Students. Research in Social Sciences and Technology, 3(3), 116-134. Retrieved from http://ressat.org/index.php/ressat/article/view/374

Aydin, H., \& Kaya, Y. (2017). Educational needs and barriers for Syrian refugee students in Turkey: A qualitative case study. Intercultural Education, 28(5), 456-473. DOI:10.1080/14675986.2017.1336373

Aydin, H. \& Kaya, Y. (2019). Education for Syrian Refugees: The New Global Issue Facing Teachers and Principals in Turkey. Educational Studies, 55(1), 46- 71. DOI: 10.1080/00131946.2018.1561454

Baynham, M. (2006). Agency and contingency in the language learning of refugees and asylum seekers. Linguistics and Education, 17(1), 24-39.

Bond, L., Giddens, A., Cosentino, A., Cook, M., Hoban, P., Haynes, A., . . . \& Glover, S. (2007). Changing cultures: Enhancing mental health and wellbeing of refugee young people through education and training. Promotion \& education, 14(3), 143-149.

Bryman, A., \& Bell, E. (2015). Business research methods. Oxford University Press, USA.

Burgoyne, U., \& Hull, O. (2007). Classroom management strategies to address the needs of Sudanese refugee learners. An adult literacy national project report. Adelaide, SA: National Centre for Vocational Education Research Ltd.

Carr, E. R., \& Incetas, Y. (2018). Perceptions \& Experiences of Non-Muslim Minority Students on the Muslim Image. Journal of Ethnic and Cultural Studies, 5(2), 43-52.

Casimiro, S., Hancock, P., \& Northcote, J. (2007). Isolation and insecurity: Resettlement issues among Muslim refugee women in Perth, Western Australia. Australian journal of social issues, 42(1), 55-69.

Cinkara, E. (2017). The role of L+ Turkish and English learning in resilience: A case of Syrian students at Gaziantep University. Journal of Language and Linguistic Studies, 13(2), 190-203.

Clark, K. (2017). Are we ready? Examining teacher's experiences supporting the transition of newly-arrived Syrian refugee students to the Canadian elementary classroom. Retrrieved from https://tspace.library.utoronto.ca/bitstream/1807/76952/1/Clark_Kathryn_201706_MT_MTRP.pdf. [18/5/2018]

Evans, W. N., \& Fitzgerald, D. (2017). The economic and social outcomes of refugees in the United States: evidence from the ACS (No. w23498). National Bureau of Economic Research. 
Frimberger, K. (2016). Towards a well-being focused language pedagogy: Enabling arts-based, multilingual learning spaces for young people with refugee backgrounds. Pedagogy, Culture \& Society, 24(2), 285299.

Gan, Z. (2013). Learning to teach English language in the practicum: What challenges do non-native ESL student teachers face?. Australian Journal of Teacher Education, 38(3), 6.

Gizatullina, A, Sibgatullina, A . (2018). Forming a Foreign Language Teacher's Professional Competencies in a Multilingual Educational Environment. Journal of Social Studies Education Research, 9 (3), 282-295. Retrieved from http://dergipark.org.tr/jsser/issue/43625/534238

Gupta, N. (2011). Business Research Methodology. Abhigyan, 29(1), 57-58.

James, G. (2018). A narrative inquiry perspective into coping mechanisms of international postgraduate students' transition experiences. American Journal of Qualitative Research, 2(1), 41-56.

Hulistijn, J. H. (2011). Language proficiency in native and nonnative speakers: An agenda for research and suggestions for second-language assessment. Language Assessment Quarterly, 8(3), 229-249.

Kagema, J. (2018). The School Curriculum and Its Influence on Teacher Motivation in Curriculum Implementation in Kenya. Journal of Culture and Values in Education, 1(1), 9-25. Retrieved from http://cultureandvalues.org/index.php/JCV/article/view/3

Kanno, Y., \& Varghese, M. M. (2010). Immigrant and refugee ESL students' challenges to accessing four-year college education: From language policy to educational policy. Journal of Language, Identity, and Education, 9(5), 310-328.

Karam, F. J., Kibler, A. K., \& Yoder, P. J. (2017). “Because even us, Arabs, now speak English”: Syrian refugee teachers' investment in English as a foreign language. International Journal of Intercultural Relations, 60, 169-182.

Lee, K. (2016). Using collaborative strategic reading with refugee English language learners in an academic bridging program. TESL Canada Journal, 97-108.

Lertola, J., \& Mariotti, C. (2017). Reverse dubbing and subtitling: Raising Pragmatic awareness in Italian English as a second language (ESL) Learners. The Journal of Specialised Translation, 28, 103-121.

Li, X., Doyle, A., Lymburner, M., \& Ghadi, N. Y. (2016). Parental Support for Newcomer Children's Education in a Smaller Centre/Soutien parental pour l'éducation des enfants des nouveaux venus dans un centre plus petit. Comparative and International Education, 45(3), 1.

MacNevin, J. (2012). Learning the Way: Teaching and Learning with and for Youth from Refugee Backgrounds on Prince Edward Island. Canadian Journal of Education, 35(3), 48-63.

Miles, J., \& Bailey-McKenna, M. C. (2016). Giving Refugee Students a Strong Head Start: The LEAD Program. TESL Canada Journal, 33, 109-128.

Miller, J. (2009). Teaching refugee learners with interrupted education in science: Vocabulary, literacy and pedagogy. International Journal of Science Education, 31(4), 571-592.

Nel, N., \& Müller, H. (2010). The impact of teachers' limited English proficiency on English second language learners in South African schools. South African Journal of Education, 30(4).

Ogilvie, G., \& Fuller, D. (2016). Restorative Justice Pedagogy in the ESL classroom: Creating a caring environment to support refugee students. TESL Canada Journal, 86-96.

Olliff, L., \& Couch, J. (2005). Pathways and pitfalls: The journey of refugee young people in and around the education system in Greater Dandenong, Victoria. Youth Studies Australia, 24(3), 42.

Perry, K. H. (2013). Becoming qualified to teach low-literate refugees: A case study of one volunteer instructor. Community Literacy Journal, 7(2), 21-38.

Popov, O., \& Erik, S. (2015). Facing the pedagogical challenge of teaching unaccompanied refugee children in the Swedish school system. Problems of Education in the 21st Century, 64, 66-74.

Reliefweb. (2018). UNHCR Jordan Factsheet - August 2018. [Online] Available at> https://reliefweb.int/report/jordan/unhcr-jordan-factsheet-august-2018 [Accessed: 25 March, 2019]

Riggs, E., Block, K., Gibbs, L., Davis, E., Szwarc, J., Casey, S., ... \& Waters, E. (2012). Flexible modESL for learning English are needed for refugee mothers. Australian Journal of Adult Learning, 52(2), 397.

Saunders, M., Lewis, P., \& Thornhill, A. (2009). Research methods for business students. Pearson education

Steele, T. J. (2017). English language teaching to Syrian refugees in transit. Online Journal of English Language Teaching (TOJELT), 2(1), 40-52.

Stevenson, J., \& Willott, J. (2007). The aspiration and access to higher education of teenage refugees in the UK. Compare, 37(5), 671-687.

Sujito, S, Budiharso, T, Solikhah, I, Mutaqin, W . (2019). The effect of analogy variations on academic writing: How Indonesian EFL students perform with different cognitive styles. Journal of Social Studies Education Research, 10 (1), 116-132. Retrieved from http://dergipark.org.tr/jsser/issue/45447/570406 
Tarman, B. \& Gürel, D. (2017). Awareness of Social Studies Teacher Candidates on Refugees in Turkey, Journal of Social Studies Research, DOI: 10.1016/j.jssr.2016.11.001

Van Rensburg, H. J., \& Son, J. B. (2010). Improving English language and computer literacy skills in an adult refugee program. International Journal of Pedagogies and Learning, 6(1), 69-81.

Watkins, P. G., Razee, H., \& Richters, J. (2012). 'I'm Telling You... The Language Barrier is the Most, the Biggest Challenge': Barriers to Education among Karen Refugee Women in Australia. Australian Journal of Education, 56(2), 126-141.

Werge-Olsen, I. B., \& Vik, K. (2012). Activity as a tool in language training for immigrants and refugees. Scandinavian journal of occupational therapy, 19(6), 530-541.

Yigit, I. H. (2018). Mass Religious Ritual and Intergroup Tolerance: The Muslim Pilgrims' Paradox. [Book Review]. Journal of Ethnic and Cultural Studies, 5(2), 196-200.

Zikmund, W. G., Babin, B. J., Carr, J. C., \& Griffin, M. (2013). Business research methods. Mason, OH: Cengage Learning.

\section{Appendix I: Interview questions}

\section{What is your age?}

2. What is your marital status?

3. What is your gender position?

4. What is your level of education?

5. How long have you stayed in Irbid, Jordan?

6. What complexities did you face in living Jordan?

7. What are your experiences about learning English in your home country?

8. Are you a learner of EFL?

9. What problems did you face from your family for learning EFL?

10. What are the social challenges for earning EFL?

11. What is your suggestion to overcome social challenges for learning EFL?

12. What is your employment status?

13. Do you think that your earning is enough to afford family expenses and EFL learning? If not

why?

14. What are the financial or economic challenges, facing by you to learn EFL?

15. What is your suggestion to overcome financial or economic challenges to learn EFL?

16. Are you comfortable with ESL learning? If not why?

17. What are the educational challenges for learning EFL?

18. What is your suggestion to overcome educational challenges?

19. Do your institution support for learning EFL? If not why?

20. Have you personally experienced any kind of institutional challenges for learning EFL? If experience what are they?

21. What is you recommendation to overcome institutional challenges? 